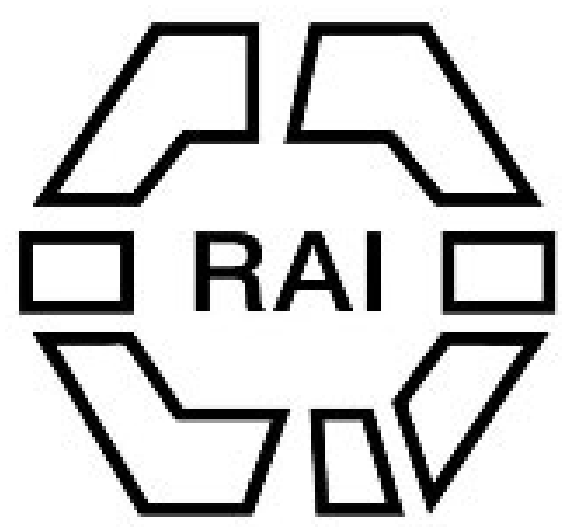

Remarks on the Caribs.

Author(s): G. H. Hawtayne

Source: The Journal of the Anthropological Institute of Great Britain and Ireland, Vol. 16 (1887), pp. 196-198

Published by: Royal Anthropological Institute of Great Britain and Ireland

Stable URL: http://www.jstor.org/stable/2841805

Accessed: 15/06/2014 07:57

Your use of the JSTOR archive indicates your acceptance of the Terms \& Conditions of Use, available at http://www.jstor.org/page/info/about/policies/terms.jsp

JSTOR is a not-for-profit service that helps scholars, researchers, and students discover, use, and build upon a wide range of content in a trusted digital archive. We use information technology and tools to increase productivity and facilitate new forms of scholarship. For more information about JSTOR, please contact support@jstor.org. 
meaningless as to defy description, and I can only advise those who are interested in such matters to examine the photograph. The original implement is part of the Atkinson collection, but is now in my care. It must have been manufactured at the cost of a very considerable amount of labour. It has been fully described and figured in "Timehri."

\section{Remarks on the CARIBS.}

\section{$B y$ G. H. Hawtayne, Esq., C.M.G.}

There is not much to be said by me in addition to what is contained in Mr. Im Thurn's paper. In the Island of St. Vincent there were and still are, two kinds of Caribs, one the yellow or red man whom the paper just read mentions, and the other a hybrid race a mixture of yellow Caribs with some African slaves who about 1632 were wrecked on the shores of Bequia, an island close to St. Vincent. Quarrels and wars arose between the two tribes, and eventually the black Caribs settled on the leeward or northwestern coast, and the yellow on the opposite side of the island. They were formidable enemies to the British, whose army of 5,000 men, led by Sir Ralph Abercrombie and other distingujshed generals, had a difficult task to subdue their savage opponents, aided by officers and men of the French Republican army. One of these black Caribs, Chatoyer, was the leader of the rebels. There is an engraving in the West Indian Court from a picture painted for Sir William Young from life, representing this savage chief and his five wives. Their features show their partly African descent, and the women are there represented carrying their loads in sunanas, which are baskets woven from a species of Maranta, strung on the back and supported by a band across the forehead, just as the figure of the Acawoi woman in the British Guiana Court is carrying hers. These black Caribs, when African slaves were imported to till the fields of the European planters, became alarmed lest their descendants might be mistaken for those of the servile race, and compelled to labour, and so the practice was instituted of compressing the foreheads of newborn children so as to distinguish them from pure Africans. This custom, however, has long died out, but skulls are to be found with receding foreheads thus caused. The Black Caribs inhabit a small tract of land near the foot of the Souffrière Mountain granted to them in 1805. They are excellent boatmen and live by fishing. They also make a few baskets of neat workmanship. In 1879 the black and yellow Caribs were said to number 431 , but of these several were not of pure blood. In 1735 they were estimated at 10,000, but many were killed in the war of 1795-6, and upward of 5,000 were transported to Ruatan in the Bay of Honduras. The prisoners of war were, however, first sent to a small island near St. Vincent, called Balliceaux, where 
several died, and where many graves containing their remains with fragments of.pottery and shells still exist. Moreover, a good many of the Black Caribs were alarmed at the eruption of the Souffrière volcano in 1812 , and quitted St. Vincent for Trinidad.

The axes, or stone implements, are found in great number in St. Vincent, Dominica, Grenada, and other islands. They are supposed by many to be "thunderbolts," and this arises possibly from their being found after a storm when the tropical rains wash away a portion of the surface land and expose these relics buried but a few inches beneath. They are still made in the far interior of Guiana.

The stone from which they are manufactured is of two or three kinds. The fine green description from which the smaller and keener edged ones are formed does not exist in St. Vincent. It may be, as Mr. Im Thurn surmises, that this stone material was brought from some distant place as an article of barter amongst the Caribs.

Various forms of these stone implements are found throughout the islands and Guiana, and I may mention that some years ago I obtained in St. Vincent a stone implement about the size and shape of a peach but as it were pinched up at one end into a thin ridge, which was perforated with a small hole. This specimen was the only one of the kind I had ever seen, until when taking it to the Christy Museum, I found some exactly similar among the Scandinavian stone implements, and which were supposed to be used as sinkers by fishermen. This will show how widely these stone weapons and tools are distributed.

There is in the New South Wales Court one sbell implement found in Duke of York's Island closely resembling the Barbadoes type, which is another noteworthy instance of distribution. The stone implements in the same case resemble those found in the West Indian Islands and British Guiana. They are, however, termed tomahawks, for which there does not appear sufficient authority.

One article of purely Carib manufacture to be seen in the British Guiana Court is the matapie, a long bag or sac woven from the rind of one of the Maranta tribe. It is so made as to become constricted when pulled longitudinally, and is used to press out from the grated root of the cassava, or manioc, the poisonous juice. The Acawoi woman already mentioned is seated on a lever by which downward pressure is sustained on the matapie, which is suspended from a beam. This appliance is also found in the West Indian Islands, and in St. Vincent is known by its French name, coulèvre.

A gentleman who recently visited the British Guiana Court informs me that a similar utensil is or was used in Fiji to squeeze out dye from a plant, but that the basket-work was so constructed as to be twisted in contrary directions when pulled, so that the vegetable mass enclosed in it was wrung instead of being simply pressed.

VOL. XVI. 
The implements found in Barbadoes are for the most part made from the centre of the conch shell, probably because that island does not contain any hard stone.

Of the Carib language little was known to the black Caribs of St. Vincent of twenty years ago, when the numerals after five were the French six, sept, huit, \&c., and the names of certain things, as knives, guns, \&c., were also given in French patois.

Interesting results would probably follow a systematic exploration of the graves of the Caribs at Balliceaux. Some years ago I made a hasty examination of one, but the bones in it were all in small fragments. Conch and other shells abounded, and I obtained several pieces of pottery, chiefly masks, rudely formed, and which appeared to have been the ears or handles of earthenware vessels. At Battewia, a neighbouring island, there is a large cave in which a wooden seat or stool was discovered, and no doubt other relics might be obtained there. There is also a Carib cave on the windward side of St. Vincent, at different spots in which island sculptured stones are found. Those which I most clearly recollect are a stone or rock in a field above the town of Barrowallie on the side of which is engraved a human face looking due west, and a large flat rock with the upper surface extensively carved, and which is supposed to have been a sacrificial altar. This is on Rutland Vale Estate, also on the leeward side. At Yambou Vale, on the windward coast, are other remains. A comparison of these rude sculptures or engravings with those found in Guiana would be most interesting.

When going round the cases in the Exhibition, a lady informed me that the "cocked hat" stones resembled closely an implement of hard clay used in the present day in Egypt to remove dried mud from the feet, and marked, as are the stones, on the flat surfaces with lines. This struck me as being very interesting.

I should like to remark in connection with what has been written by Mr. Im Thurn as to semi-lunar ornaments of silver having been given to Chiefs of the Red men, the form of which was presumably copied from stone articles of a similar form, that it is on record that when the Chief of the Black Caribs of St. Vincent, Chatoyer, was killed in the Carib war of 1794, upon him was found a silver semilunar ornament with an inscription, which had been given to him by William IV, when Prince William Henry, and serving in the Navy; but this semi-lunar ornament was evidently copied from the gorget then worn by military officers, and of which specimens are common. It may be therefore that the Dutch semi-lunar ornaments spoken of by Mr. Im Thurn were also imitations or adaptations of the gorget formerly worn by military men.

\section{Note by Hyde Clarke, Esq., Vice-President.}

Among Mr. Borlase's gold ornaments in the West Indian Court, it will be observed that the hand of most of the human figures consists of three fingers, the feet also have three toes. 